\title{
Sustainable Development Reporting: Evidence from Thailand
}

\author{
Muttanachai Suttipun ${ }^{1}$ \\ ${ }^{1}$ Department of Accountancy, Faculty of Management Sciences, Prince of Songkla University, Thailand \\ Correspondence: Muttanachai Suttipun, Department of Accountancy, Faculty of Management Sciences, Prince of \\ Songkla University, 90110, Thailand. Tel: 66-88-784-6614. E-mail: muttanachai.s@psu.ac.th
}

Received: February 28, 2015 Accepted: April 9, 2015 Online Published: May 16, 2015

doi:10.5539/ass.v11n13p316

URL: http://dx.doi.org/10.5539/ass.v11n13p316

\begin{abstract}
The aims of this research are to investigate the extent of sustainable development (SD) reporting in the 2005-2012 annual reports of listed companies in the Stock Exchange of Thailand (SET) and to determine the relationships between corporate characteristics and the level of SD reporting. The sample size was 100 SET-listed firms in the SET. In addition, this research utilized content analysis by word count to quantify the level of SD reporting. The findings indicated an increase in the SD reporting level among the sampled SET-listed firms during the study period. The disclosures on economic aspect were the most prominent, followed by social and environmental reporting. Moreover, the levels of SD reporting varied between small and large firms and between state and private companies. The research results also showed the associations of company size, industry type, ownership status and corporate social responsibility accomplishments to the level of SD reporting.
\end{abstract}

Keywords: sustainable development reporting, Thailand, annual reports

\section{Introduction}

Corporate sustainable development involves attempts to align organizations' offerings with stakeholders' demands, thereby necessitating the businesses to become socially and environmentally responsible in addition to meeting the economic expectations (Mahoney, 2012). The sustainable development (SD) reporting is thus an accounting framework that incorporates three aspects of corporate performance: economic, social and environmental aspects. In fact, the practice of SD reporting was first devised in the mid-1990s by John Elkington (1997). In addition, SD reporting differs from the conventional economic reporting in that the former encompasses not only the economic aspect but also the social and environmental aspects. However, the means of measurement for the social and environmental aspects are indefinite.

Thus, the ultimate goal of businesses has been shifted from profit maximization to wealth maximization since, unlike in the past when the owners of financial resources (i.e. creditors, shareholders, investors) were given the priority, business organizations at present are required to satisfy the expectations of diverse and myriad stakeholders, e.g. customers, employees, regulators, the community (Elkington, 1997). Therefore, an increasing number of corporations have nowadays adopted SD reporting as a means to disseminate operational-performance information to their stakeholders (KPMG, 2008). The SD reporting is mandatory in most of the advanced economies; however, in Thailand, only economic reporting is mandatory, whereas the reporting on social and environmental issues is voluntary. The voluntary nature of social and environmental reporting has contributed to asymmetric information, especially with respect to corporate SD practices. Nevertheless, a large number of corporations have opted to disclose social and environmental information on a voluntary and selective basis due to the lack of social and environmental accounting standards and regulations (Larrinaga et al., 2002).

The scope of SD reporting in Thailand is still debatable since it is a concept that extends beyond the economic aspect of corporate responsibility to encompass several other important aspects. Although the Stock Exchange of Thailand (SET) has imposed the comply-or-explain rule (Lint, 2009) by which the SET-listed companies are required to provide social and environmental disclosures in the annual reports (Suttipun, 2012), the information in the disclosures is mostly narrative and qualitative, rather than quantitative, in nature (Ratanajongkol et al., 2006).

In addition, even though empirical studies on SD reporting were extensively conducted in advanced nations, e.g. Australia, Canada, Japan, New Zealand, the U.S., and many European countries (Ho \& Taylor, 2007; Kolk et al., 2001), research on the topic in less advanced economies is very limited, particularly in Thailand, where 
stakeholders could exercise little power to pressure the businesses to make available social and environmental information (Suttipun, 2012). In fact, there exists no prior research on the trend in SD reporting by SET-listed companies, thus contributing to a lack of evidence on the extent, type, trend and level of SD reporting of Thai corporations. In addition, the causal relationship between the SD reporting and corporate characteristics is inconclusive. Furthermore, although the stakeholder theory has been able to explain the SD reporting practices in developed countries (Larrinaga et al., 2002; Monteiro \& Guzman, 2010); its explanatory ability has never been proven in the setting of developing countries. According to Elkington (1997), Larrinaga et al. (2002) and Carrol and Bucholtz (2006), the concept of SD reporting is widely recognized, but its definitions are so varied and generalized that the operationalization and measurement of SD and its various perspectives are hampered.

Hence, the objectives of this research are to investigate the extent of SD reporting in the 2005-2012 annual reports of SET-listed companies and to examine the relationships between the various corporate characteristics and the level of SD reporting. In other words, this research study has endeavored to answer these three questions: (1) what is the extent of SD reporting in the 2005-2012 annual reports? (2) What is the nature of SD reporting in the 2005-2012 annual reports? And (3) which of the corporate characteristics do influence the level of SD reporting during the study period?

It is expected that the research findings would contribute to a better understanding of the SD reporting practices, especially in less advanced economies, among researchers and financial practitioners. In addition, it is believed that the results would shed light on the relationships between SD reporting and the various corporate characteristic factors. The research results would also benefit creditors, investors and shareholders who typically rely on non-financial SD reports for investment decisions. Moreover, Thai regulatory bodies could apply some of the findings to streamlining the current SD disclosure practices. The study results could also serve as a barometer that informs the general public as to how socially and environmentally responsible the sampled SET-listed companies were.

The organization of this research is as follows: Section I is the introduction. Section II is related to the theoretical perspective, and Section III deals with the hypothesis development. Section IV outlines the research methodology, including sample selection, variable measurement and data analysis. Section V discusses the research findings, while the concluding remarks are provided in the final section.

\section{Theoretical Perspective}

A plethora of financial and accounting theories have referred to the SD reporting concept and also attempted to define the influencing factors of the level of SD reporting. Examples of them are the agency theory (Mele, 2008), legitimacy theory (Ahmad \& Sulaiman, 2004; Islam \& Deegan, 2010), stakeholder theory (Gray et al., 1998; Llena et al., 2007; Larrinaga et al., 2002), media setting agenda theory (Brown et al., 2009), institution theory (Amran \& Devi, 2008), and social political theory (Cheng \& Fan, 2010). In this research, the heterogeneous demands for information of diverse stakeholders are however an important research area in which both the extent and level of SD information disclosures are investigated from both theoretical and empirical perspectives (Monteiro \& Guzman, 2010; Llena et al., 2007; Larrinaga et al., 2002). In addition, the SD concept has been gaining greater recognition among businesses and their stakeholders. The stakeholder theory is thus employed in this research study.

According to Gray et al. (1998), the stakeholder theory is concerned with the management of the relationships between diverse stakeholders and the corporate responsibility to the stakeholders. Since the effective management of stakeholder relationships proves crucial to corporate image and competitive advantage, more resources are allocated to managing such relationships, including the provision of more information, albeit often in the form of voluntary disclosures, in the annual reports. The justification is that stakeholders, i.e. those who have a stake in an organization (Collier, 2008), have something at risk as well as the power to influence the organization, including its actions, decisions, policies or goals. Potential stakeholders include shareholders, creditors, suppliers, regulators, customers, competitors, employees, employees' families, the media, the local community, local charities, and future generations (Carrol \& Bucholtz, 2006). At present, many corporations are being closely monitored for their actions not only by shareholders and investors but also by several other stakeholders, e.g. customers, creditors, suppliers, the community, as well as the environmental activists. This fact reflects the increased demands from numerous stakeholder groups and the significance of social and environmental problems associated with globalization (Soderstrom, 2013).

According to Gray et al. (1996), identification of stakeholders is carried out by businesses so as to ascertain which groups need managing to further the interests of the corporations. The stakeholder theory suggests that businesses manage the relationships between stakeholders based on various factors, e.g. the nature of the task 
environment, the salience of stakeholder groups, and the values of decision makers who determine the stakeholder ranking process (Donaldson \& Preston, 1995). In addition, management tends to attach greater importance to the information demands of those stakeholders whose actions determine the corporation's ongoing survival, rather than providing equal treatment to all stakeholders (Nasi et al., 1997). The influence of stakeholders and their expectations are nonetheless constantly changing, so businesses are required to adjust their operating and reporting behaviors (Deegan, 2001). In short, the stakeholder theory views corporations as part of a social system while focusing on the various stakeholder groups within the society (Ratanajongkol et al., 2006).

The stakeholder theory views the SD practice as a means to achieve wealth maximization. On the one hand, a corporation is obligated to meet the economic demands of its capital owners and to maximize the market value. On the other hand, other stakeholders' demands, particularly those of customers and laborers, also dictate the directions of corporate activity and actions. Thus, based on the stakeholder theory, the significance that the firms attach to an activity or project is directly and positively correlated to the influence that a particular stakeholder group has.

\section{Hypothesis Development}

The definition of SD reporting in this research is public reporting by corporations to provide their internal and external stakeholders with a view of corporate position and activity on economic, social, and environmental aspects. Existing literature on SD reporting has attempted to explain why companies provide SD information (Cowen et al., 1987; Hackston \& Milne, 1996). The terminologies for SD reporting vary greatly, examples of which are the sustainability reporting, sustainable development reporting, corporate social responsibility reporting, triple bottom line reporting, and accountability reporting. Jose and Lee (2007) and Kolk et al. (2001) noted the variations in SD reporting across countries. Meanwhile, Ho and Taylor (2007) and Deegan and Rankin (1996) examined types of SD disclosures and content in the annual reports. In addition, the influences of specific pressure groups (Deegan \& Gordon, 1996) and media attention (Brown et al., 2009) on the content of SD disclosures were investigated.

This research has proposed six hypotheses developed based on prior studies. For instance, Ho and Taylor (2007) found the associations between company size, profitability, liquidity as well as industry type and the level of SD reporting in the annual reports, the stand-alone reports, and on the websites of the 50 largest US and Japanese firms. Suttipun (2012) found the relationship of industry type and ownership status to the level of environmental reporting in the 2010 annual reports of SET-listed companies. Deegan and Gordon (1996) noted that Australian firms that have received social and environmental awards tend to disclose more social and environmental information than those that have never earned such an award. In Canada, Cormier and Gordon (2001) found that, unlike private companies, state enterprises disclosed more social and environmental information. In Sweden, Tagesson et al. (2009) also found that state enterprises provided more social and environmental disclosures than private firms for the reason that the state-owned companies are subjected to more scrutiny by the owner (i.e. the state) and the mass media. Joshi and Gao (2009) reported the relationships between company size, audit type as well as profitability and the level of social disclosures on the websites of 49 multinationals.

According to the stakeholder theory, larger companies are accountable to more stakeholders than are smaller firms and thereby are required to disclose more information (Cowen et al., 1987). Deegan and Gordon (1996); Choi (1999); Cormier and Gordon (2001); Raar (2002); Ho and Taylor (2007); and Kunsirikun and Sherer (2004) reported a positive association between the amounts of non-financial information disclosures (i.e. social and environmental disclosures) and company size. Nevertheless, Davey (1982) and Roberts (1992) found no such relationship. This study hypothesizes that a positive relationship exists between company size and the level of SD reporting in the annual reports.

\section{H1: There is a positive relationship between company size and the level of SD reporting.}

In several previous studies, companies were classified, among various criteria, into high- or low-profile businesses (Patten, 1992; Hackston \& Milne, 1996; Choi, 1999). High-profile businesses refer to those in highly environmentally sensitive industries (Stray \& Ballantain, 2000; Ho \& Taylor, 2007). These companies would thus be more closely monitored than those in industries with minimal impact on society and environment (i.e. low-profile companies) (Newson \& Deegan, 2002). Furthermore, extensive research studies, e.g. Choi 1999; Stray and Ballantine 2000; Newson and Deegan 2002; Ahmad and Sulaiman 2004; Ho and Taylor 2007, found that high-profile companies disclosed more social and environmental information than low-profile companies. It is thus hypothesized that there is a positive relationship between the industrial environmental impact and the level of SD reporting in the annual reports.

H2: There is a positive relationship between industry type and the level of SD reporting. 
In this research, the sampled companies are classified into either state or private enterprises based on the proportion of common shares held by the state. If at least 51 percent of a firm's common shares are held by the state, it is a state enterprise. On the other hand, if at least 51 percent of the firm's common shares are owned by private institutions or individuals, the company is regarded as private.

Ownership status is however often overlooked in previous research on social and environmental reporting. This is probably attributable to the fact that previous studies were mostly conducted in the Anglo-American context where government ownership is less common (Tagesson et al., 2009). In addition, disparities in the quantity and quality of SD disclosures exist between state and private enterprises. In Canada, Cormier and Gordon (2001) found that state enterprises disclosed more social and environmental information than their private counterparts. In Sweden, Tagesson et al. (2009) reported that, due to more scrutiny from the major owner (i.e. the state) and the media, state-owned companies usually comply with the expectations of society by disclosing more social and environmental information relative to private organizations. Nonetheless, in less developed economies, the research results are the opposite. For instance, Balal (2000) argued that Bangladeshi private companies disclosed more environmental information than government companies. Despite the differences in findings, this study hypothesizes that government companies have a higher level of SD disclosures than do private companies.

\section{H3: There is a relationship between ownership status and the level of SD reporting.}

Larger audit firms are generally believed to carry out an accounting audit more independently than do smaller audit firms (Joshi \& Gao, 2009) since the former would sustain greater damage to their reputations than the latter in case of a sub-standard audit. In addition, companies with greater potential gains from external monitoring would engage the services of larger audit firms, e.g. the Big4. The Big4 are the largest auditing firms consisting of KPMG, Price Waterhouse Cooper, Deloitte, and Ernst \& Young. The findings with respect to auditor type and social and environmental disclosures are nonetheless inconclusive (Inchausti, 1997; Joshi \& Gao, 2009). Thus, it is hypothesized that companies that engage the services of a Big4 audit firm have a higher level of SD reporting than those that engage a non-Big4 audit firm.

H4: There is a positive relationship between type of auditor and the level of SD reporting.

To encourage a larger number of SET-listed companies to embrace the SD reporting practice, the Stock Exchange of Thailand (SET) has since 2006 conferred a CSR award to the organizations that have implemented the practice. However, the findings on the relationship between CSR award and the level of SD reporting are inconclusive. On the one hand, Deegan and Gordon (1996) found that companies that have been given social and environmental awards tend to provide more social and environmental information than those that have never received such an award. On the other hand, Raar (2002) found no relationship between both variables. This research study hypothesizes that there is a positive relationship between CSR awards and the level of SD reporting.

\section{H5: There is a positive relationship between CSR awards and the level of SD reporting.}

A company's country of origin has been found to influence the quantity of social and environmental disclosures (Kolk et al., 2001). Niskala and Pretes (1995); Hackston and Milne (1996); and Jahamani (2003) reported a positive association between the company's country of origin and amounts of corporate social and environmental disclosures. Hence, the sampled SET-listed companies are divided into two types: local and international companies. The classification leads to a hypothesis that there is a relationship between and a company's country origin and the level of SD reporting.

H6: There is a relationship between country of origin and the level of SD reporting.

\section{Methodology}

This section deals with sample selection, dependent and independent variables (i.e. variable measurement), and data analysis.

\subsection{Sample Selection}

Out of a total of 489 SET-listed companies, a sample of 100 firms was selected by the simple random sampling method. The source of SD reporting data was the 2005-2012 annual reports of the sampled SET-listed companies since the reports are a conveniently accessible source of information and mandatorily made available every year (Amran \& Devi, 2008). Thus, the sampled companies are those that have been listed on the SET since 2004 or earlier and whose accounting year-end falls on $31^{\text {st }}$ December. Nevertheless, those under rehabilitation were excluded from the samples. The examination of data was carried out between July 2013 and June 2014. 


\subsection{Dependent Variable}

This research has employed content analysis to quantify the level of SD reporting in the 2005-2012 annual reports of the SET-listed sampled companies. Content analysis can be carried out by ways of sentence count, page count, line count and word count; however, the measurement of this research was by word count since, according to Krippendorf (1980), words are the smallest unit of measurement to analyze and thereby provide the maximum robustness in assessing the quantity of information disclosures. In addition, words are a preferred measure when it comes to gauging the amount of space dedicated to a topic and to ascertaining its significance. Due to certain characteristics of the Thai language (i.e. the local language used in the annual reports), e.g. no full stop at the end of sentences, certain data collection methods, e.g. sentence count, are inapplicable. Similarly, page count is not applicable since the annual reports of the sampled companies came in myriad sizes, fonts and spacing.

As previously mentioned, the content analysis of this research was carried out using Thai-language SD disclosures since the majority of the sampled SET-listed firms' annual reports were in Thai-language. This is consistent with the stakeholder theory in that the listed companies must serve their Thai stakeholders whose mother tongue is Thai. In addition, there exist two prior studies on voluntary reporting based on non-English disclosure data, i.e. Choi (1999), who studied environmental disclosures of Korean firms based on the Korean-language version of annual reports; and Balal (2000), who used the Bangladeshi-language version of annual reports to investigate voluntary disclosures of Bangladeshi corporations.

To assist corporations with SD disclosures, many reporting guidelines have been proposed and published; however, one that is widely recognized is by the Global Reporting Initiative (GRI, 2006). Thus, this research utilizes the GRI 3.1 Reporting Guidelines (2011) in measuring the SD reporting contained in the annual reports (Ho \& Taylor, 2007).

\subsection{Independent Variables}

In this research, dummy variables were used for all six independent variables, i.e. company size (Deegan \& Gordon, 1996; Choi, 1999; Cormier \& Gordon, 2001; Raar, 2002; Ho \& Taylor, 2007), industry type (Stray \& Ballantain, 2000; Ho \& Taylor, 2007), ownership status (Tagesson et al., 2009), CSR award (Deegan \& Gordon, 1996), country of origin (Kolk et al., 2001), and audit type (Inchausti, 1997; Joshi \& Gao, 2009). The data pertaining to the independent variables were gleaned from the annual reports and the SET website (2012). Table 1 presents the definitions and measurements of all variables under study, i.e. one dependent variable and six independent variables.

Table 1. Summary of variable measurement

\begin{tabular}{ll}
\hline $\begin{array}{l}\text { Dependent variable } \\
\text { SD reporting } \\
\text { Independent variables }\end{array}$ & $\begin{array}{l}\text { Measurement } \\
\text { Content analysis (word count) of the 2005-2012 annual reports } \\
\text { Measurement }\end{array}$ \\
\hline Size of company & $1=$ Top 50 firms, $0=$ Non-top 50 firms \\
Type of industry & $1=$ High profile industry, $0=$ Low profile industry \\
Ownership status & $\begin{array}{l}1=\text { Government firms, } 0=\text { Private firms } \\
\text { CSR Award }\end{array}$ \\
Country of origin & $1=$ Win CSR award, $0=$ Never win CSR award \\
Audit type & $1=$ Big 4 auditors, $0=$ Non-big 4 auditors \\
\hline
\end{tabular}

\subsection{Data Analysis}

Data were manually coded twice prior to importing to a word processing program (i.e. Microsoft ${ }^{\circ}$ Word) for word count to determine the amount of SD disclosure in the annual reports. Two sets of coded data were compared and adjusted for any differences between the first and second coding sessions for further analysis by the SPSS program.

In data analysis, descriptive analysis and repeated measure analysis were used. The descriptive analysis was used to analyze the extent and quantity of SD reporting of the sampled SET-listed companies based on frequency, percentage, mean and standard deviation. The repeated measure analysis was employed to test the existence of relationships between the influencing factors and the level of SD reporting in the 2005-2012 annual reports of 
the sampled SET-listed companies.

\section{Findings and Discussion}

Table 2 presents the extent of corporate SD reporting during 2005-2012 of the sampled companies. It can be observed that the extent of SD reporting (i.e. the number of words) in the annual reports of the sampled SET-listed companies increased from 7267.56 words in 2005 to 10215.20 words in 2012, equivalent to an increase of 40 percent in the eight-year period.

Table 2. The extent of SD reporting during $2005-2012$

\begin{tabular}{lllllllll}
\hline \multirow{2}{*}{ Perspective } & \multicolumn{2}{l}{ Year (Average number of words) } & & & & & \\
& $\mathbf{2 0 0 5}$ & $\mathbf{2 0 0 6}$ & $\mathbf{2 0 0 7}$ & $\mathbf{2 0 0 8}$ & $\mathbf{2 0 0 9}$ & $\mathbf{2 0 1 0}$ & $\mathbf{2 0 1 1}$ & $\mathbf{2 0 1 2}$ \\
\hline Economic & 4582.86 & 4748.61 & 4889.21 & 5282.54 & 5280.98 & 5797.56 & 6145.05 & 6189.58 \\
Social & 1516.74 & 1689.24 & 1938.19 & 1916.46 & 2336.97 & 2466.41 & 2593.57 & 2673.41 \\
Environmental & 770.49 & 887.26 & 947.70 & 961.11 & 1259.85 & 1329.93 & 1398.78 & 1472.99 \\
SD reporting & 7267.56 & 7732.87 & 8368.52 & 8498.39 & 9155.60 & 9624.68 & 10033.4 & 10215.2 \\
\hline
\end{tabular}

In addition, it is found that the economic aspect of SD reporting is the most common disclosure, followed by the social and environmental aspects. The results are consistent with a study by Brown et al. (2009), who reported an increase in SD reporting of construction firms due to information demands from the shareholders and investors. This is because the owners of financial resources still exert more influence than any other stakeholder with regard to corporate disclosure (Deegan, 2001); and because the non-financial SD reporting (i.e. the social and environmental disclosures) is still on a voluntary basis. However, in percentage term, in the research the environmental reporting had the largest increase of 91 percent during 2005-2012, followed by the social (77 percent) and economic perspectives (35 percent).

Table 3. Independent sample t-test

\begin{tabular}{llllll}
\hline Group & & Mean & S.D. & t & p-value \\
\hline \multirow{2}{*}{ Firm size } & Top50 & 12345.45 & 9157.05 & 4.507 & $0.000^{* *}$ \\
& Non-top50 & 6539.76 & 3274.28 & & \\
Industry type & High profile & 9755.17 & 9142.27 & 0.971 & 0.334 \\
& Low profile & 8359.65 & 5257.62 & & \\
Country & Domestic & 9179.89 & 7335.80 & 1.098 & 0.275 \\
& International & 7060.85 & 3094.56 & & \\
Ownership & Government & 19081.25 & 17716.20 & 4.430 & $0.000^{* *}$ \\
& Private & 8092.85 & 4711.75 & & \\
Audit type & Big-4 auditors & 9263.15 & 4949.99 & 0.774 & 0.441 \\
& Non-big-4 auditors & 8148.93 & 9470.91 & & \\
CSR award & Have award & 10456.54 & 4008.76 & 1.121 & 0.265 \\
\hline
\end{tabular}

** significant at $0.01, *$ significant at 0.05

To test the level of intra-group SD reporting of each of the six independent variables, i.e. company size, industry type, country of origin, ownership status, auditor type and CSR award, this research has utilized independent sample t-test, as presented in Table 3. It is found that the level of intra-group SD reporting is significantly different for the independent variables of firm size and ownership status at the 0.01 significance level. Nevertheless, the level of intra-group SD reporting is insignificantly different for the variables of industry type, country of origin, audit type and CSR award ( $p>0.05)$.

This research has also used repeated measures ANOVA to identify an upward trend in SD reporting in the 2005-2012 annual reports of the sampled SET-listed companies (Table 4). The findings indicate a significant increase in SD reporting for economic, social and environmental disclosures at the 0.01 significance level. This 
is consistent with Kunsirikun and Sherer (2004), who reported a significant increase in environmental disclosures in the 1993-1999 annual reports of SET-listed companies.

Table 4. The trend in SD reporting

\begin{tabular}{|c|c|c|c|c|c|}
\hline Aspect & Type III sum of squares & df & Mean & $\mathbf{F}$ & Sig. \\
\hline Economic & 99108305.72 & 7 & 14158329.39 & 8.555 & $0.000^{* *}$ \\
\hline Social & 131791255.70 & 7 & 18827322.25 & 33.709 & $0.000 * *$ \\
\hline Environmental & 49662745.42 & 7 & 7094677.92 & 26.569 & $0.000^{* *}$ \\
\hline TBL & 806426438.20 & 7 & 115203776.90 & 38.532 & $0.000 * *$ \\
\hline
\end{tabular}

** significant at $0.01,{ }^{*}$ significant at 0.05

To investigate the relationships between corporate characteristics and the level of SD reporting in the annual reports of the sampled SET-listed companies, repeated measures ANOVA was again used. In Table 5, it can be observed that a positive relationship exists between company size, industry type, ownership status and CSR award and the level of SD reporting at the 0.01 significance level. The results are consistent with Ho and Taylor (2007), Suttipun (2012), Deegan and Gordon (1996), Newson and Deegan (2002), Choi (1999), Raar (2002), and Cormier and Gordon (2001), who reported the significant relationship between size of company, type of industry, ownership status and CSR award and the level of non-financial reporting, e.g. CSR reporting, environmental reporting and SD reporting. On the other hand, country of origin and audit type exhibit no influence on the level of SD reporting $(\mathrm{p}>0.05)$.

Table 5. The relationship between corporate characteristics and SD reporting

\begin{tabular}{llllll}
\hline Sources & Type III sum of squares & df & Mean & F & Sig. \\
\hline Intercept & 24699780158 & 1 & 24699780158 & 199.876 & 0.000 \\
Size of company & 852980754.2 & 1 & 852980754.2 & 6.903 & $0.010^{* *}$ \\
Type of industry & 7660191647 & 1 & 7660191647 & 61.988 & $0.000^{* *}$ \\
Ownership status & 1684667536 & 1 & 1684667536 & 13.633 & $0.000^{* *}$ \\
CSR Award & 4891165251 & 1 & 4891165251 & 39.580 & $0.000^{* *}$ \\
Country of origin & 458013586.1 & 1 & 458013586.1 & 1.205 & 0.275 \\
Audit type & 228830046.2 & 1 & 228830046.2 & 0.599 & 0.441 \\
\hline
\end{tabular}

** significant at $0.01, *$ significant at 0.05

With regard to company size, prior studies (Raar, 2002; Ho \& Taylor, 2007; Suttipun, 2012) found that larger firms made financial and non-financial information more readily available than their smaller counterparts since the former are required to serve different demands of more diverse stakeholders, which is consistent with the findings of this research.

In addition, it is normal that stakeholders would expect from companies in high-profile industry to disclose more information associated with possible impacts of their operations on economy, society and environment. Thus, the results on the relationship between industry type and the level of SD reporting of this research are consistent with Newson and Deegan (2002); Choi (1999); Ho and Taylor (2007).

With respect to ownership status, the research finding is consistent with those conducted in Canada by Cormier and Gordon (2001) and in Sweden by Tagesson et al. (2009), both of whom reported that state enterprises disclosed more social and environmental information than did private companies. This is because state-owned companies are subject to more scrutiny by the owner (i.e. the state) and mass media.

The finding also shows a positive "carry-over" effect of past CSR award achievements on the level of SD reporting. In Thailand, the ThaiPat Institute, a non-profit organization, has since 2006 been conferring CSR awards to SET-listed companies whose actions and activities promote sustainable development. To win the CSR award, a company has to engage in various SD activities, including SD reporting. Based on the stakeholder theory, CSR award-winning firms in advanced economies (Deegan \& Gordon, 1996) and less advanced 
economies (refer to this current research study) would attempt to meet their stakeholders' demand for information through SD reporting. This is similar to the finding of Deegan and Gordon (1996), who found that CSR award-winning companies disclosed more social and environmental information than those without a CSR award.

Table 6. Summary of hypothesis test results

\begin{tabular}{llll}
\hline Hypothesis & Independent variables & Predicted sign & Results \\
\hline H1 & Size of company & + & Accept \\
H2 & Type of industry & + & Accept \\
H3 & Ownership status &,+- & Accept \\
H4 & Audit type & + & Reject \\
H5 & CSR Award & + & Accept \\
H6 & Country of origin &,+- & Reject \\
\hline
\end{tabular}

Table 6 summarizes the test results of the hypotheses that examine the relationships between the independent variables of company size, industry type, ownership status, CSR award, country of origin and audit type; and the level of SD reporting (i.e. the dependent variable). Out of the total of six hypotheses (H1-H6), only four (H1, H2, $\mathrm{H} 3, \mathrm{H} 5)$ are accepted.

\section{Conclusions}

This research has attempted to investigate the extent of SD reporting in the 2005-2012 annual reports of Thai SET-listed companies and to determine the relationships between the various corporate characteristics and the level of SD reporting. The findings showed an upward trend in the level of SD reporting in the annual reports of the sampled SET-listed companies during 2005-2012. The most prominent was economic disclosures, followed by social and environmental reporting. It was found that the levels SD reporting were significantly different between small and large firms (i.e. the company size variable) and between state and private firms (i.e. the ownership status variable). In addition, the results indicated the associations of company size, industry type, ownership status and CSR award to the level of SD reporting.

According to the stakeholder theory, large firms are more readily recognizable than smaller firms, and such high visibility typically leads to greater attention from stakeholders and the media. The theory also mentions the importance of management of diverse stakeholders and greater transparency through information disclosure. This research has found that larger Thai SET-listed companies disclosed more, in terms of both length and breadth of information, in comparison with their smaller counterparts.

Apparently, this study is the first to investigate the factors influencing the SD reporting in the annual reports of Thai SET-listed companies. In addition, it is expected that the insights into the SD reporting practices of SET-listed companies would enormously contribute to literature on sustainability accounting. This study has also revealed that stakeholders' information demands play a crucial role in the level of SD reporting.

Two main limitations of this research study are the sole reliance on the annual reports for analysis data and the exclusion of certain corporate characteristic factors. In fact, corporations communicate with stakeholders through numerous communication channels, such as stand-alone reports and websites, in addition to annual reports. Furthermore, the level of SD reporting could be influenced by other factors of corporate characteristics, e.g. corporate governance, age of business. Thus, future research study should include other communication channels for SD disclosure and encompass additional possible influencing factors of the level of SD reporting.

\section{Acknowledgments}

The author is deeply indebted to the Thailand Research Fund, Prince of Songkla University, and the Higher Education Research Promotion and National Research University Project of Thailand, Office of the Higher Education Commission, Thailand for financial support. In addition, sincere appreciation goes to Associate Professor Somkao Runglertkrengkrai for invaluable advice and encouragement.

\section{References}

Ahmad, N. N. N., \& Sulaiman, M. (2004). Environmental disclosures in Malaysian annual reports: A legitimacy theory perspective. International Journal of Commerce and Management, 14, 44-58. http://dx.doi.org/ $10.1108 / 10569210480000173$ 
Amran, A., \& Devi, S. (2008). The impact of government and foreign affiliate influence on corporate social reporting: The case of Malaysia. Managerial Auditing Journal, 23(4), 386-404. http://dx.doi.org/10.1108/02 686900810864327

Balal, A. R. (2000). Environmental reporting in developing countries: Empirical evidence from Bangladesh. Eco-Management and Auditing, 7, 114-121. http://dx.doi.org/10.1002/1099-0925(200009)7:3<114:: AID-EMA131>3.0.CO;2-E

Brown, H. S., de Jong, M., \& Levy, D. L. (2009). Building institutions based on information disclosure: Lessons from GRI's sustainable reporting. Journal of Cleaner Production, 17, 571-580. http://dx.doi.org/10.1016/j. jclepro.2008.12.009

Carrol, A., \& Bucholtz, A. K. (2006), Business and Society: Ethics and Stakeholder Management. Thompson, New York.

Cheng, L. H., \& Fan, H. K. (2010). Drivers of environmental disclosure and stakeholder expectation: Evidence from Taiwan. Journal of Business Ethics, 96, 435-451. http://dx.doi.org/10.1007/s10551-010-0476-3

Choi, J. S. (1999). An investigation of the initial voluntary environmental disclosures made in Korean semi-annual financial reports. Pacific Accounting Review, 11, 73-102.

Collier, P. M. (2008). Stakeholder accountability: A field study of the implementation of a governance improvement plan. Accounting, Auditing \& Accountability Journal, 21, 933-953. http://dx.doi.org/10.1108/ 09513570810907429

Cormier, D., \& Gordon, I. M. (2001). An Examination of Social and Environmental Reporting Strategies. Accounting, Auditing \& Accountability Journal, 14, 587-616. http://dx.doi.org/10.1108/EUM000000000 6264

Cowen, S. S., Ferreri, L. B., \& Parker, L. D. (1987). The impact of corporate characteristics on social responsibility disclosure: A typology and frequency-base analysis. Accounting, Organizations and Society, 12, 111-122. http://dx.doi.org/10.1016/0361-3682(87)90001-8

Davey, H. B. (1982). Corporate social responsibility disclosure in New Zealand: An empirical investigation. Un-published working paper Massey University, Palmerton North.

Deegan, C. (2001). Financial Accounting Theory. McGraw-Hill Book Company Australia Pty Limited, Roseville.

Deegan, C., \& Gordon, B. (1996). A Study of the Environmental Disclosure Practices of Australian Corporations. Accounting and Business Research, 26, 187-199. http://dx.doi.org/10.1080/00014788.1996.9729510

Deegan, C., \& Rankin, R. (1996). Do Australian companies report environmental news objectively? An analysis of environmental disclosures by firms prosecuted successfully by the environmental protection authority. Accounting, Auditing \& Accountability Journal, 9(2), 50-67. http://dx.doi.org/10.1108/09513579610116358

Donaldson, T., \& Preston, L. (1995). The stakeholder theory of the corporation: Concepts, evidence and implications. Academy of Management Review, 20(1), 65-91. http://dx.doi.org/10.2307/258887

Elkington, J. (1997). Cannibals with Forks - the Triple Bottom Line of Twenty-first Century Business. Mankato, $\mathrm{MN}$ : Capstone.

Global Reporting Initiative (GRI). (2006). Sustainability reporting guidelines: version 3.0. GRI, Amsterdam.

Global Reporting Initiative (GRI). (2011). Sustainability reporting guidelines: version 3.1. GRI, Amsterdam.

Gray, R., Collison, D., \& Bebbington, J. (1998). Environmental and social accounting and reporting. Financial Reporting Today: Current Trends and Emerging Issues, 1-9.

Gray, R., Owen, D., \& Adams, C. (1996). Accounting and accountability: changes and challenges in corporate and social reporting. Prentice Hall, London.

Hackston, D., \& Milne, M. J. (1996). Some determinants of social and environmental disclosures in New Zealand companies. Accounting, Auditing \& Accountability Journal, 9, 77-108. http://dx.doi.org/10.1108/0 9513579610109987

Ho, L. J., \& Taylor, M. E. (2007). An empirical analysis of triple Bottom-line reporting and its determinates: Evidence from the United States and Japan. Journal of International Financial Management and Accounting, 18, 123-150. http://dx.doi.org/10.1111/j.1467-646X.2007.01010.x 
Inchausti, G. B. (1997). The influence of company characteristics and accounting regulation on information disclosed by Spanish firms. European Accounting Review, 6, 45-68. http://dx.doi.org/10.1080/09 6381897336863

Islam, M., \& Deegan, C. (2010). Media pressures and corporate disclosure of social responsibility performance information: A study of two global clothing and sports retail companies. Accounting and Business Research, 40(2), 131-148. http://dx.doi.org/10.1080/00014788.2010.9663388

Jahamani, Y. F. (2003). Green accounting in developing countries: the case of U.A.E. and Jordan. Managerial Finance, 29(8), 37-45. http://dx.doi.org/10.1108/03074350310768418

Jose, A., \& Lee, S. M. (2007). Environmental reporting of global corporation: A content analysis based on website disclosure. Journal of Business Ethics, 72(4), 307-321. http://dx.doi.org/10.1007/s10551-006 $-9172-8$

Joshi, P. L., \& Gao, S. S. (2009). Multinational Corporate Social and Environmental Disclosures (CSED) on Websites. International Journal of Commerce \& Management, 19, 27-44. http://dx.doi.org/10.1108/1056 9210910939654

Kolk, A., Walhain, S., \& Wateringen, S. (2001). Environmental Reporting by the Fortune Global 250: Exploring the Influence of Nationality and Sector. Business Strategy and the Environment, 10(1), 15-28. http://dx.doi.org/10.1002/1099-0836(200101/02)10:1<15::AID-BSE275>3.0.CO;2-Y

KPMG. (2008). KPMG International Survey of Corporate Responsibility Reporting 2008. KPMG International: The Netherlands.

Krippendorf, K. (1980), Content analysis: An introduction to its methodology. Sage, New York.

Kunsirikun, N., \& Sherer, M. (2004). Corporate social accounting disclosure in Thailand. Accounting, Auditing \& Accountability Journal, 17(4), 629-660. http://dx.doi.org/10.1108/09513570410554588

Larrinaga, C., Carrasco, F., Correa, C., Llena, F., \& Moneva, J. M. (2002). Accountability and accounting regulation: the case of Spanish environmental disclosure standards. The European Accounting Review, 11, 723-740. http://dx.doi.org/10.1080/0963818022000001000

Lint, L. W. (2009). Corporate social and environmental disclosure in emerging securities markets. North Carolina Journal of International Law and Commercial Regulation, 35(1), 1-32.

Llena, F., Monera, J. M., \& Hernandez, B. (2007). Environmental disclosure and compulsory accounting standards: the case of Spanish annual reports. Business Strategy and the Environment, 16, 50-63. http://dx.doi.org/10.1002/bse.466

Mele, D. (2008). Corporate social responsibility theories, In Crane, the Oxford handbook of corporate social responsibility. Oxford University Press, New York. http://dx.doi.org/10.1093/oxfordhb/9780199211593. 003.0003

Monteiro, S. M., \& Guzman, B. A. (2010). The influence of the Portuguese environmental accounting standard on the environmental disclosures in the annual reports of large companies operating in Portugal: A first view (2002-2004). Management of Environmental quality: An International Journal, 21, 414-435. http://dx.doi.org/10.1108/14777831011049070

Nasi, J., Nasi, S., Philip, N., \& Zylidopoulos, S. (1997). The evolution of corporate social responsiveness-an exploratory study of Finnish and Canadian forestry companies. Business \& Society, 38(3), 296-321. http://dx.doi.org/10.1177/000765039703600305

Newson, M., \& Deegan, C. (2002). Global expectations and their association with corporate social disclosure practices in Australia, Singapore, and South Korea. The International Journal of Accounting, 37, 183-213. http://dx.doi.org/10.1016/S0020-7063(02)00151-6

Niskala, M., \& Pretes, M. (1995). Environmental reporting in Finland: A note on the use of annual reports. Accounting, Organizations and Society, 20, 457-466. http://dx.doi.org/10.1016/0361-3682(94)00032-Q

Patten, D. (1992). Intra-industry environmental disclosures in response to the Alaskan oil spill: A note on legitimacy theory. Accounting, Organizations and Society, 17, 471-475. http://dx.doi.org/10.1016/0361 -3682(92)90042-Q

Raar, J. (2002). Environmental initiatives: Towards triple-bottom line reporting. Corporate Communications, 7 , 169-183. http://dx.doi.org/10.1108/13563280210436781 
Ratanajongkol, S., Davey, H., \& Low, M. (2006). Corporate social reporting in Thailand, the news is all good and increasing. Qualitative Research in Accounting\& Management, 3(1), 67-83. http://dx.doi.org/10.1108 /11766090610659751

Roberts, R. (1992). Determinants of corporate social responsibility disclosure: An application of stakeholder theory. Accounting, Organizations and Society, 17, 595-612. http://dx.doi.org/10.1016/0361-3682(92) 90015-K

Soderstrom. (2013). Sustainability reporting: Past, present, and trend for the future. Insights Melbourne Business and Economics, 13, 31-37.

Stray, S., \& Ballantine, J. (2000). A sectorial comparison of corporate environmental reporting and disclosure. Eco-Management and Auditing, 7, 165-177. http://dx.doi.org/10.1002/1099-0925(200012)7:4<165::AIDEMA138>3.0.CO;2-2

Suttipun, M. (2012). Triple Bottom Line Reporting in Annual Reports: A Case Study of Companies Listed on the Stock Exchange of Thailand (SET). Asian Journal of Finance\& Accounting, 4, 69-92. http://dx.doi.org/10.5296/ajfa.v4i1.1289

Tagesson, T., Blank, V., Broberg, P., \& Collin, S. O. (2009). What Explains the Extent and Content of Social and Environmental Reporting in Swedish Listed Corporations? Corporate Social Responsibility and Environmental Management, 16, 352-364. http://dx.doi.org/10.1002/csr.194

The Stock Exchange of Thailand (SET). (2012). Report on corporate governance. Bangkok, Thailand: Boonsiri Printing Company Limited.

\section{Copyrights}

Copyright for this article is retained by the author(s), with first publication rights granted to the journal.

This is an open-access article distributed under the terms and conditions of the Creative Commons Attribution license (http://creativecommons.org/licenses/by/3.0/). 